\title{
Phenolic content and antioxidant capacity in organically and conventionally grown eggplant (Solanum melongena) fruits following thermal processing
}

\author{
Erika Leonor ZAMBRANO-MORENO ${ }^{1}$, Rosa Nilda CHÁVEZ-JÁUREGUI ${ }^{1,2 *}$, \\ María de Lurdes PLAZA ${ }^{1,2}$, Linda WESSEL-BEAVER ${ }^{2}$
}

\begin{abstract}
Thermal processing and production practices used in vegetables can cause changes in their phytochemical contents. Eggplant is characterized by its high antioxidant content. The objective of this work was to determine levels of anthocyanins, polyphenols, and flavonoids and antioxidant capacity in organically and conventionally grown eggplant prepared fresh or subjected to one of three thermal preparation methods: boiling, baking or steaming. The soluble and hydrolyzable polyphenols and flavonoids content were quantified by Folin-Ciocalteu and Aluminum chloride methods, respectively. Anthocyanins were quantified according to the $\mathrm{pH}$ differential method. Antioxidant capacity was determined by DPPH and ORAC methods. The results showed differences between organic and conventional eggplant for some variables although cultivation method did not have a consistent effect. Hydrolysable polyphenol content was greater, and soluble and hydrolysable antioxidant capacities were higher in organically grown eggplant, while anthocyanin content was greater in conventionally grown eggplant. Fresh eggplant produced under conventional cultivation had a much greater content of anthocyanins compared to that of other cultivation method-thermal treatment combination. In general, steamed eggplant contained higher total polyphenol and flavonoid levels as well as greater antioxidant capacity. Steamed eggplant from both conventional and organic systems also had high amounts of anthocyanins compared to other thermal treatments.
\end{abstract}

Keywords: eggplant; antioxidant capacity; organic; boiled; steamed, baked.

Practical Application: Eggplant is characterized by its high antioxidant content. In order to elucidate the possible benefits of the consumption of organic eggplant as part of a whole diet, information is needed on anthocyanin and polyphenol content as well as antioxidant capacity in organically and conventionally grown eggplant prepared fresh or subjected to one of three thermal preparation methods: boiling, baking, or steaming. Results from this study could be used as a part of a database providing information on the effects of different cooking methods on the antioxidant potential of eggplant.

\section{Introduction}

Nutritional quality of vegetables can vary depending on the cultivation method used. Organic cultivation is a growing trend world-wide with 164 countries producing organic products in 2014 , and a total value of $\$ 64$ billion of products being sold (Willer \& Lernoud, 2014). Whether there are greater nutritional benefits in organic compared to conventional fruits and vegetables is still a much-debated subject.

The beneficial influence of fruit on human health is linked with the presence of specific phytochemicals. Determining the nature of these compounds in different products, and the influence of preharvest, postharvest and processing treatments have been major areas of study in food research (Cools et al., 2011).

Fruits are most commonly consumed raw; however, vegetables often undergo some type of processing before being ingested. Cooking is often the final step in at-home food processing. Vegetables are commonly cooked either by simple boiling, microwaving or stir-frying before being consumed. Cooking processes induce significant changes in the physical characteristics as well as chemical composition of the vegetables and thus influence the concentration and bioavailability of compounds (Zhang \& Hamauzu, 2004; Azizah, 2009; Donado-Pestana et al., 2012).

Following exposure to certain cooking processes, fruits and vegetables can present significant losses of some antioxidants such as ascorbic acid and some carotenoids. However, polyphenol and flavonoid content can increase and show certain stability when they are exposed to high temperatures, a quality that is reflected in the preservation of their antioxidant capacity (Faller \& Fialho, 2009). For example, Dewanto et al. (2002) found significant increases in the content of total free phenolics in sweet corn after thermal treatment involving increased heating times and temperatures.

Eggplant is among the top ten vegetables for its oxygen radical absorbance capacity due to its phenolic constituents, which have important health benefits (Singh et al., 2009; Akanitapichat et al., 2010). Eggplant needs to be cooked before being eaten. It is generally consumed after frying, boiling in 
water or grilling. Some recent studies have shown that thermal treatment increases its antioxidant content (Braga et al., 2011; Das et al., 2011). However, it is not known how antioxidant content and activity might vary depending on how eggplant is produced at the field level, nor what, if any interactions might occur between the eggplant production system and postharvest thermal treatment of this vegetable. Therefore, the objective of this work was to determine the total polyphenol, flavonoid and anthocyanin content and their antioxidant capacity in organically and conventionally produced eggplant subjected to three thermal treatments (boiling, steaming and baking) compared to fresh eggplant used as a control (no thermal treatment).

\section{Materials and methods}

\subsection{Preparation of samples and thermal treatments}

Eggplant fruits (cv. Dancer) were obtained from two commercial farms near Guánica, Puerto Rico, one using organic and the other using conventional cultivation practices. Sixteen mature eggplant fruits were selected from each cultivation system. Fruits were washed with potable water, disinfected with $200 \mathrm{mg} / \mathrm{L}$ sodium hypochlorite, washed again, and dried with paper towels. Four fruits from each cultivation system were randomly assigned to each of four treatments (fresh-control, boiling, steaming and baking). For fresh, boiled or steamed treatments, fruits were cut into approximately $1 \mathrm{~cm}^{2}$ cubes. For baking treatment, fruits were cut in half longitudinally. Cooking times for boiling, steaming and baking were determined by preliminary tests adapted from the methodology proposed by Faller \& Fialho (2009). A covered stainless steel pot was used to boil $100 \mathrm{~g}$ of sample in $200 \mathrm{ml}$ water for seven minutes. After boiling, water was drained and samples were cooled to room temperature using a cold water bath in a stainless steel receptacle. In a similar manner, $100 \mathrm{~g}$ of sample was steamed for seven minutes in a food steamer, then drained and cooled as previously described. In the baking treatment, samples were placed into a conventional oven at $180^{\circ} \mathrm{C}$ for 25 minutes, transferred to a stainless steel and cooled in a water bath as above. In order to minimize possible oxidation, processed samples were packed into plastic Ziploc ${ }^{\circ}$ bags. Air was manually removed from the bags before sealing and then immediately stored at $-80^{\circ} \mathrm{C}$ until elaboration of extracts.

\subsection{Chemicals and reagents}

Potassium chloride, Sodium acetate, Methanol, Sodium carbonate, Sodium hydroxide, Hydrochloric acid and acetone reagents were purchased from VWR Advanced Instruments, LLC (Manatí, Puerto Rico, USA). Folin-Ciocalteu, 2,2-Diphenyl-1-picrylhydrazyl (DPPH), 6-Hydroxy-2,5,7,8-tetramethylchroman-2-carboxylic acid (Trolox) and (+)-Catechin reagents were purchased from Sigma-Aldrich (St. Louis, MO, USA). Gallic acid, Sodium nitrite, Aluminum chloride, Fluorescein and 2,2'-Azobis [2-amidinopropane] dihydrochloride (AAPH) were purchased from Fisher Scientific (Pittsburgh, PA, USA). All other reagents were of analytical quality grade.

\subsection{Preparation of extracts}

Approximately $5 \mathrm{~g}$ of each processed fruit was macerated with $40 \mathrm{ml}$ methanol: $\mathrm{HCl} 12 \mathrm{M}(99: 1, \mathrm{v} / \mathrm{v})$ for determination of anthocyanins, $20 \mathrm{ml}$ methanol:water $(50: 50, \mathrm{v} / \mathrm{v})$ for determination of soluble polyphenols and flavonoids, and $20 \mathrm{ml}$ methanol-water:HCl 1.2 M (50:50, v/v) for hydrolyzable polyphenols and flavonoids. Samples were quantitatively transferred to centrifuge tubes and stirred for $60 \mathrm{~min}$ at $38 \pm 2.0^{\circ} \mathrm{C}$. Polyphenols and flavonoids detained were carried to a second extraction with $20 \mathrm{ml}$ acetone:water $(70: 30, \mathrm{v} / \mathrm{v})$. After this procedure, the solutions were centrifuged at $1200 \mathrm{~g}$ for $30 \mathrm{~min}$ and were filtered on Whatman ${ }^{\mathrm{TM}}$ \# 1 paper (GE Healthcare Bio- Sciences, Pittsburgh, Pennsylvania, USA) using a vacuum pump. Supernatants from extractions were combined and made up to $50 \mathrm{ml}$ with distilled water (Todaro et al., 2009; Rufino et al., 2010).

\subsection{Phytochemical analysis}

\section{Total anthocyanins}

Total anthocyanins content was determined using the $\mathrm{pH}$ differential method according to official method AOAC 37.1.68 (Association of Official Analytical Chemists, 2006). Two different dilutions of samples were prepared, one with $\mathrm{pH} 1.0$ buffer solution (Potassium chloride $0.025 \mathrm{M}$ ) and the second with $\mathrm{pH}$ 4.5 buffer solution (Sodium acetate $0.4 \mathrm{M}$ ). The $\mathrm{pH}$ was adjusted with concentrated Hydrochloric acid. The appropriate dilution factor was determined by diluting the extract with $\mathrm{pH} 1.0$ buffer, the absorbance at $530 \mathrm{~nm}$ should be less than 1.2. Using this dilution factor, were prepared two dilutions of the samples, one with $\mathrm{pH} 1.0$ buffer and the other with $\mathrm{pH} 4.5$ buffer. After $20 \mathrm{~min}$, the absorbance was measured at $530 \mathrm{~nm}$ and $700 \mathrm{~nm}$ using a Spectronic Genesys TM8 spectrophotometer (Thermo Electron Scientific Instruments, Madison, Wisconsin, USA). Total anthocyanin content was calculated using the Equation 1:

$$
\text { Total anthocyanin }=\frac{A^{*} M W^{*} D F^{* 1000}}{\varepsilon^{*} L}
$$

where, MW is anthocyanin cyanidin-3-glucoside molecular weight $(=449.2 \mathrm{~g} / \mathrm{mol}), D F$ is the dilution factor, $\varepsilon$ is the molar absorptivity coefficient $\left(=34,300 \mathrm{~L} / \mathrm{mol}^{*} \mathrm{~cm}\right)$ and $L$ is the pathlength $(=1 \mathrm{~cm})$. Results were expressed as cyanidin-3-glucoside equivalents (Cyd-3-gluE) in $\mathrm{mg}$ per $100 \mathrm{~g}$ fresh weight (mg Cyd-3-gluE/100 g FW).

\section{Determination of polyphenol content}

Soluble and hydrolysable total polyphenols content were determined using the microscale protocol named Folin-Ciocalteu colorimetry (Waterhouse, 2002). A $20 \mu$ l volume of blank, standard or extract was placed into an assay tube to which was added $1580 \mu \mathrm{l}$ distilled water and $100 \mu \mathrm{l}$ Folin-Ciocalteu reagent. The mixture was allowed to stand for $6 \mathrm{~min}$ in darkness at room temperature. After this time, $300 \mu \mathrm{l}$ of $20 \%$ sodium carbonate solution was added and the mixture was swirled and incubated for $120 \mathrm{~min}$ at room temperature. Finally, the absorbance was measured at $760 \mathrm{~nm}$ using a Spectronic Genesys TM8 spectrophotometer (Thermo Electron Scientific Instruments, Madison, Wisconsin, USA). Soluble and hydrolyzable total polyphenols contents were 
calculated using a standard curve of gallic acid. The results were expressed as gallic acid equivalents (GAE) in mg per $100 \mathrm{~g}$ fresh weight (mg GAE/100 g FW) (Akanitapichat, et al., 2010).

\section{Flavonoids analysis}

Soluble and hydrolysable total flavonoids content were determined using the aluminum chloride colorimetric method. A $500 \mu \mathrm{l}$ volume of blank, standard or extract, was mixed with $1250 \mu \mathrm{l}$ distilled water and $75 \mu \mathrm{l}$ of $5 \%$ sodium nitrite solution and the mixture was allowed to stand for $6 \mathrm{~min}$ in darkness at room temperature. Then, $150 \mu \mathrm{l}$ of $10 \%$ aluminum chloride solution was added and the mixture was allowed to stand for another 5 min before adding $500 \mu \mathrm{l}$ of $1 \mathrm{M}$ sodium hydroxide solution and made up to $3000 \mu \mathrm{l}$. The absorbance was measured at $510 \mathrm{~nm}$ using a Spectronic Genesys TM8 spectrophotometer (Thermo Electron Scientific Instruments, Madison, Wisconsin, USA). The soluble and hydrolyzable total flavonoids contents were calculated using a standard curve of $(+)$-catechin and the results were expressed as catechin equivalents (CE) in mg per $100 \mathrm{~g}$ fresh weight (mg CE/100 g FW) (Akanitapichat, et al., 2010).

\section{Oxigen Radical Absorbance Capacity (ORAC)}

Antioxidant capacity was determined using the ORAC method (Oxygen Radical Absorbance Capacity), accord to methodology described by Cao \& Prior (Cao \& Prior, 1999) and Huang et al. (2002). A fMax 96-well plate fluorometer (Molecular Devices, Sunnyvale, California, USA) was utilized with an excitation wavelength of $485 \mathrm{~nm}$ and an emission wavelength of $538 \mathrm{~nm}$ with the Ascent ${ }^{\mathrm{TM}}$ Software version 2.6 (Thermo Scientific). A $50 \mu \mathrm{l}$ volume of blank ( $\mathrm{pH} 7.0$ buffer solution (Potassium $0.75 \mathrm{M}$ and Sodium $0.75 \mathrm{M})$ ), standard or extract, $100 \mu \mathrm{l}$ of $500 \mathrm{nM}$ fluorescein solution and $50 \mu \mathrm{l}$ of $900 \mathrm{mg}$ per $10 \mathrm{ml} \mathrm{AAPH}$ solution (2,2'-Azobis [2-amidinopropane] dihydrochloride), were directly placed into the 96-well plate. The reduction of fluorescein was recorded for $70 \mathrm{~min}$. The antioxidant capacity was calculated using a standard curve of Trolox and the results were expressed as Trolox equivalents (TE) in $\mu$ mol per $g$ fresh weight ( $\mu \mathrm{mol} \mathrm{TE} / \mathrm{g} \mathrm{FW})$.

\section{DPPH radical-scavenging capacity}

Antioxidant capacity was also determined using the DPPH modified method (2,2-Diphenyl-1-picrylhydrazyl radical) described by Faller \& Fialho (2009). A $100 \mu \mathrm{M}$ DPPH solution was prepared with $80 \%$ methanol giving approximately an absorbance of $1.0 \pm 0.1$ at $515 \mathrm{~nm}$. A $200 \mu \mathrm{l}$ volume of blank ( $80 \%$ methanol), standard or extract was mixed with $2800 \mu \mathrm{l}$ DPPH solution. After $20 \mathrm{~min}$, absorbance was measured using a Thermo Spectronic Genesys TM8 spectrophotometer (Thermo Electron Scientific Instruments, Madison, Wisconsin, USA). The percentage radical scavenging capacity (\%RSC) was calculated with the Equation 2:

$$
\% R S C=\frac{\left(A_{0}-A_{f}\right)}{A_{0}}
$$

where $A_{0}$ is the absorbance of the DPPH solution alone measured at time zero and $A_{f}$ is the absorbance for each sample after 20 minutes following the addition of the DPPH solution.
The antioxidant capacity was calculated using a standard curve of \%RSC vs. Trolox concentration and the results were expressed as Trolox equivalents (TE) in $\mu \mathrm{mol}$ per $\mathrm{g}$ fresh weight ( $\mu \mathrm{mol} \mathrm{TE} / \mathrm{g} \mathrm{FW}$ ) (Leyva, 2009).

\subsection{Statistical analysis}

Data were analyzed as a completely randomized $2 \times 4$ factorial ( 2 cultivation systems $\mathrm{x} 4$ processing methods) design with four replications. Both factors were considered to be fixed effects. Analysis of variance was performed using InfoStat (Di Rienzo et al., 2013). The significance of the interaction and main effects were determined using an $\mathrm{F}$ test, and means were separated using Fisher's least significant difference multiple comparison test.

\section{Results and discussion}

With one exception (total monomeric anthocyanins, Table 1), there were no significant cultivation system by thermal treatment interactions (Tables 2 and 3). In general, relative differences between preparation methods were the same whether fruits came from the organic or conventional cultivation system. Even in the case of total monomeric anthocyanins, the relative ranking of thermal treatments were similar under the two cultivation systems: fresh and steamed eggplant had the highest amounts of anthocyanin, and boiled and baked eggplant had the lowest amounts of anthocyanin under both cultivation systems (Table 1).

Organic eggplant had only about a third as much total monomeric anthocyanins compared to conventionally produced eggplant (Table 1). However, In contrast, organic eggplant had a significantly higher content of hydrolysable polyphenols (Table 2)

Table 1. Mean total monomeric anthocyanins in fresh and cooked eggplant grown under conventional and organic cultivation systems in Puerto Rico.

\begin{tabular}{lcc}
\hline \multicolumn{1}{c}{ Treatment $^{1}$} & $\begin{array}{c}\text { Total monomeric anthocyanins } \\
\text { (mg Cyd-3-gluE/100 g FW) }\end{array}$ \\
\hline Cultivation system x thermal treatment interaction & \\
Conventional - fresh (control) & 6.31 & $\mathrm{~d}$ \\
Conventional - boiled & 2.5 & $\mathrm{~b}$ \\
Conventional - baked & 0.16 & $\mathrm{a}$ \\
Conventional - steamed & 4.2 & $\mathrm{c}$ \\
Organic - fresh (control) & 1.19 & $\mathrm{ab}$ \\
Organic - boiled & 0.42 & $\mathrm{a}$ \\
Organic - baked & 0.27 & $\mathrm{a}$ \\
Organic - steamed & 2.46 & $\mathrm{~b}$ \\
LSD (0.05) & 1.58 & \\
Significance of F test & & \\
Cultivation system & $* *$ & \\
Thermal treatment & $* *$ & \\
Interaction & $* *$ & \\
CV & $49.4 \%$ & \\
\hline
\end{tabular}

${ }^{1}$ Due to the presence of a significant interaction, only cultivation system by thermal treatment means are presented. Cyd-3-gluE $=$ Cyanidin-3-glucoside equivalents. LSD $=$ Fishers least significant difference test at the 0.05 probability level. Means followed by the same letter are not significantly different. ${ }^{*}=$ Significant at the 0.05 and 0.01 probability level. 
and higher soluble and hydrolysable antioxidant capacities when the ORAC method was used (Table 3). There was no difference between organic and conventionally grown eggplant for the other phenolic content and antioxidant capacities measured (Tables 2 and 3 ).
Among thermal preparation methods, steamed eggplant had the highest levels of polyphenols and flavonoids (Table 2). Fresh eggplant had the lowest levels of these two phenolics, although the difference was not always significantly different from levels in boiled or baked eggplant. Total monomeric anthocyanin

Table 2. Mean total polyphenol and flavonoid content (soluble and hydrolysable) in fresh and cooked eggplant grown under conventional and organic cultivation systems in Puerto Rico.

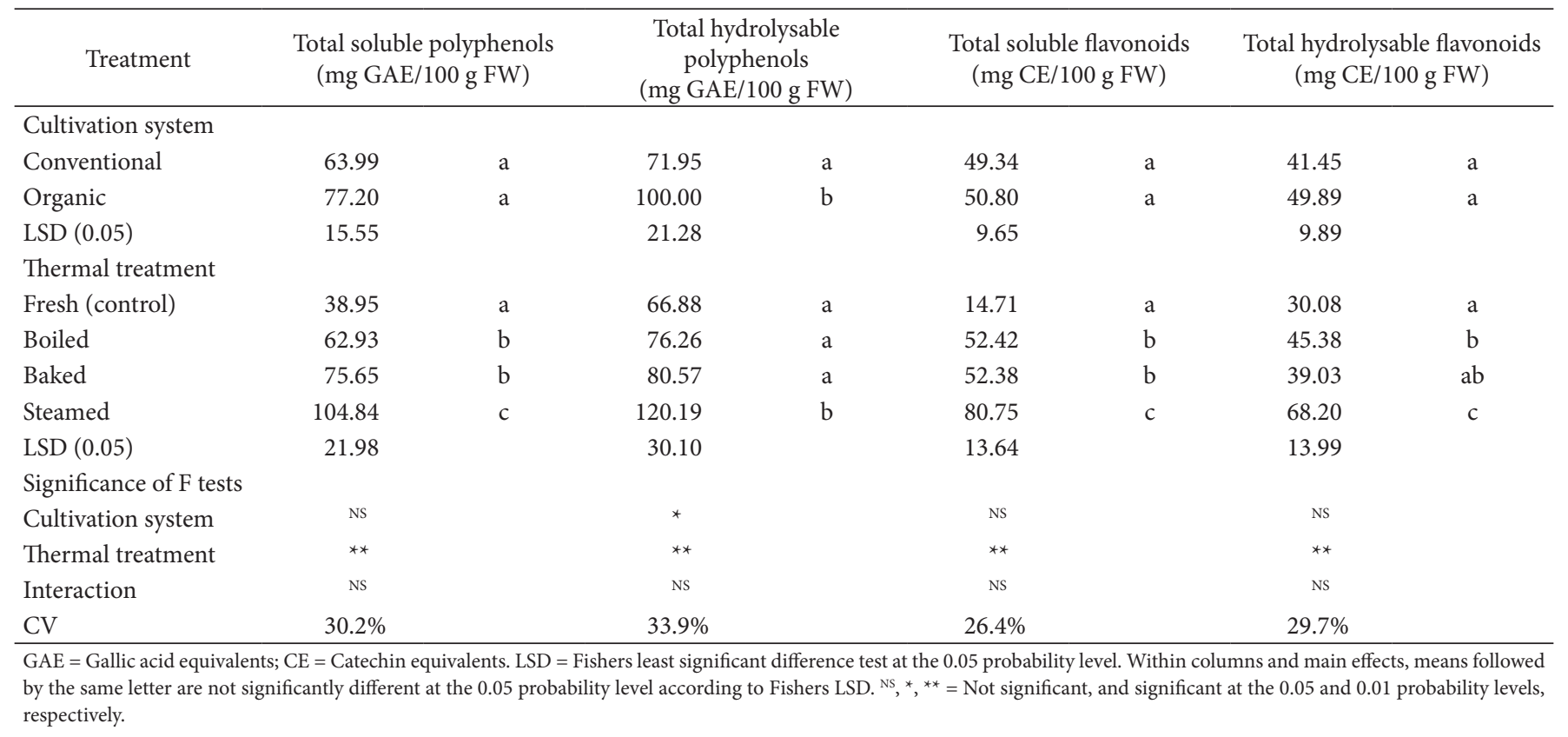

Table 3. Mean antioxidant capacity (ORAC and DPPH) in fresh and cooked eggplant grown under conventional and organic cultivation systems in Puerto Rico.

\begin{tabular}{|c|c|c|c|c|c|c|c|c|c|c|c|c|}
\hline \multirow{2}{*}{$\begin{array}{c}\text { Treatment } \\
\text { Cultivation system }\end{array}$} & \multicolumn{2}{|c|}{$\begin{array}{l}\text { Soluble antioxidant } \\
\text { capacity (ORAC) } \\
(\mu \mathrm{mol} \mathrm{TE} / \mathrm{g} \mathrm{FW})\end{array}$} & \multicolumn{2}{|c|}{$\begin{array}{c}\text { Hydrolyzable } \\
\text { antioxidant capacity } \\
(\text { ORAC }) \\
(\mu \mathrm{mol} \text { TE/g FW })\end{array}$} & \multicolumn{2}{|c|}{$\begin{array}{c}\text { Anthocyanin } \\
\text { antioxidant capacity } \\
(\text { ORAC }) \\
(\mu \mathrm{mol} \mathrm{TE} / \mathrm{g} \mathrm{FW})\end{array}$} & \multicolumn{2}{|c|}{$\begin{array}{c}\text { Soluble antioxidant } \\
\text { capacity (DPPH) } \\
(\mu \mathrm{mol} \text { TE/g FW) }\end{array}$} & \multicolumn{2}{|c|}{$\begin{array}{c}\text { Hydrolyzable } \\
\text { antioxidant capacity } \\
(\mathrm{DPPH}) \\
(\mu \mathrm{mol} \mathrm{TE} / \mathrm{g} \mathrm{FW})\end{array}$} & \multicolumn{2}{|c|}{$\begin{array}{c}\text { Anthocyanin } \\
\text { antioxidant capacity } \\
(\mathrm{DPPH}) \\
(\mu \mathrm{mol} \mathrm{TE} / \mathrm{g} \mathrm{FW})\end{array}$} \\
\hline & $\mathrm{em}$ & & & & & & & & & & & \\
\hline Conventional & 36.61 & $\mathrm{a}$ & 47.71 & $\mathrm{a}$ & 68.18 & $\mathrm{a}$ & 48.06 & $\mathrm{a}$ & 67.38 & $\mathrm{a}$ & 97.95 & $\mathrm{a}$ \\
\hline Organic & 50.60 & $\mathrm{~b}$ & 75.06 & $\mathrm{~b}$ & 68.79 & $\mathrm{a}$ & 62.41 & a & 62.11 & $\mathrm{a}$ & 73.25 & $\mathrm{a}$ \\
\hline LSD (0.05) & 11.96 & & 16.61 & & 14.92 & & 14.97 & & 16.00 & & 31.79 & \\
\hline \multicolumn{13}{|c|}{ Thermal treatment } \\
\hline $\begin{array}{l}\text { Fresh } \\
\text { (control) }\end{array}$ & 12.56 & $\mathrm{a}$ & 37.93 & $\mathrm{a}$ & 49.03 & $\mathrm{a}$ & 15.89 & $\mathrm{a}$ & 51.70 & $\mathrm{a}$ & 59.35 & $\mathrm{a}$ \\
\hline Boiled & 49.32 & $\mathrm{~b}$ & 62.74 & $\mathrm{~b}$ & 66.74 & $\mathrm{a}$ & 59.15 & $\mathrm{~b}$ & 65.87 & $a b$ & 72.35 & a \\
\hline Baked & 43.66 & $\mathrm{~b}$ & 52.46 & $\mathrm{ab}$ & 63.52 & $\mathrm{a}$ & 61.3 & $\mathrm{~b}$ & 61.48 & $\mathrm{ab}$ & 77.26 & $\mathrm{a}$ \\
\hline Steamed & 68.88 & c & 92.40 & $\mathrm{c}$ & 94.65 & $\mathrm{~b}$ & 84.61 & c & 79.93 & $\mathrm{~b}$ & 133.44 & $\mathrm{~b}$ \\
\hline LSD (0.05) & 16.92 & & 23.48 & & 21.10 & & 21.17 & & 22.63 & & 44.95 & \\
\hline \multicolumn{13}{|c|}{ Significance of F tests } \\
\hline $\begin{array}{l}\text { Cultivation } \\
\text { system }\end{array}$ & * & & ** & & NS & & NS & & NS & & NS & \\
\hline $\begin{array}{l}\text { Thermal } \\
\text { treatment }\end{array}$ & $* *$ & & ** & & $* *$ & & $* *$ & & NS & & * & \\
\hline Interaction & NS & & NS & & NS & & NS & & NS & & NS & \\
\hline $\mathrm{CV}$ & $37.6 \%$ & & $37.1 \%$ & & $29.9 \%$ & & $37.1 \%$ & & $33.9 \%$ & & $50.9 \%$ & \\
\hline
\end{tabular}


levels among the four preparation methods were affected by the type of cultivation system (significant interaction, $p=0.0007$ ) (Table 1). Overall, anthocyanin levels were considerably higher in conventionally grown eggplant, and levels were significantly different for each preparation method. The highest amount of anthocyanin was found in fresh eggplant, followed by steamed, boiled and baked eggplant. In organically grown eggplant, anthocyanin levels on average were much lower with the highest level observed in steamed eggplant, and no differences observed among the other three preparation methods.

Total anthocyanin content in fresh eggplant fruit produced under conventional cultivation (6.31 mg Cyd-3-gluE/100 g) was more than five times greater than under organic cultivation (1.19 mg Cyd-3-gluE/100 g) (Table 1). Boiled and steamed fruits from conventional cultivation also had high anthocyanin content. Skin color of fruits produced under conventional cultivation was noticeably less faded in color, possibly due to these fruits being harvested earlier on average than fruits produced under the organic production system. Eggplant skin color fades when harvest of fruit is delayed as was possibly the case in the organically grown eggplant. Anthocyanin content observed in organically produced fresh eggplant in this study (1.19 mg Cyd-3-gluE/100 g) (Table 1) was comparable to the amount reported by Sadilova et al. (2006) (1.65 mg Del-3-gluE/100 g). Anthocyanin content in the conventionally grown fresh eggplant (6.31 mg Cyd-3-gluE/100 g) was similar to results reported by Braga et al. (2011) (7.0 Cyd-3-gluE/100 g) and Koponen et al. (2007) (7.5 mg Cyd-3-gluE/100 g). Large differences in anthocyanin content observed in this and previous studies suggest that not only differences in cultivation practices between an organic and conventional system, but differences in harvest practices between any two cultivation systems may have an impact on anthocyanin content in eggplant.

Hydrolysable polyphenol content was significantly higher in organic eggplant compared to conventional eggplant. A similar, although non-significant, trend was observed for soluble polyphenols and soluble and hydrolysable flavonoids: their content was higher in organic versus conventional eggplant (Table 2). Lima et al. (2008) and Raigón et al. (2010) also reported greater polyphenols and flavonoids content in organic eggplant. Raigón et al. (2010) concluded that polyphenols and flavonoids content is lower in conventionally grown eggplant due to higher levels of fertilization, especially nitrogen, which results in phenolic content reduction. The presence of pathogens in organic agriculture due to minimal use of pesticides might also explain higher content of polyphenols since these substances can be used as a mechanism of pest protection in plants (Asami et al., 2003).

Soluble polyphenol content in this study (38.95 mg AGE/100 g) was 19\% less than that reported by Raigón et al. (2008) (48.26 mg AGE/100 g), although those authors studied several different eggplant varieties and did not include the variety in our study. Hydrolysable polyphenol content in the current study (66.88 mg AGE/100 g) was $12 \%$ higher than reported by Concellón et al. (2012). Soluble and hydrolysable flavonoid contents in this study were lower than those reported by Fategbe et al. (2012). The variability in soluble and hydrolysable flavonoid content can depend on the eggplant variety used and the predominant flavonoid type, an observation also point out by Cao et al. (2010).

Soluble antioxidant capacity by the ORAC method in fresh eggplant $(12.56 \mu \mathrm{mol} \mathrm{TE} / \mathrm{g}$, Table 3$)$ was similar to results reported by Isabelle et al. (2010) ( $12.78 \mu \mathrm{mol} \mathrm{TE} / \mathrm{g})$. However, Isabelle et al. (2010) values were higher than those reported by Cao et al. (1996) $(3.9 \mu \mathrm{mol} \mathrm{TE} / \mathrm{g})$. Hydrolysable antioxidant capacity in fresh eggplant $(37.93 \mu \mathrm{mol} \mathrm{TE} / \mathrm{g})$ was higher than reported by Wu et al. (2004) $(25.09 \mu \mathrm{mol} \mathrm{TE} / \mathrm{g})$. The conditions under which a crop is grown affects antioxidant capacity (Huang et al., 2009) and could explain these contrasting results.

Our study was conducted using the same cultivar ('Dancer') under both organic and conventional cultivation systems. Nevertheless, the inferences that can be made concerning the effect of cultivation system (organic vs. conventional) are limited due to the fact that the fruit was produced at a single location and in only one cultivation year. Cultural practices within a particular organic or conventional system can also vary widely. The authors were not able to obtain detailed information concerning, for example, total amounts of nutrients applied in the two cultivation systems sampled in the study, although it is likely that larger amounts of nutrients (nitrogen in particular) were applied in the conventional system. Previous studies comparing organic and conventional systems have suffered from similar design deficiencies. A study sampling eggplant produced from multiple organic and conventional farms in various locations is needed to make stronger inferences about the differences between these two systems in terms of phenolic compounds content and antioxidant capacity.

In general, anthocyanin content decreased with cooking treatments, except with the steaming treatment in organically grown eggplant (Table 1). Baking resulted in a greater loss of anthocyanins (94\%) than boiling (61\%) and steaming (11\%). An anthocyanin loss after boiling was also reported by Braga et al. (2011). The reduction in content might be explained by the fact that anthocyanin is present primarily in the eggplant peel which is in more direct contact with heat that causes its decomposition.

Soluble and hydrolysable polyphenols and flavonoids generally increased when eggplant was subjected to thermal treatments whether the fruits came from the organic or conventional cultivation system (Table 2). Compared to fresh eggplant, soluble polyphenols content increased up to almost $60 \%$ with the boiling treatment, $94 \%$ with the baking treatment and as much as $169 \%$ with the steaming treatment. Braga et al. (2011) reported that boiled eggplant had $77 \%$ more polyphenols than fresh eggplant. These increases are due to the release of antioxidants that occurs following the thermal destruction of the cellular wall and subcellular compartments. In addition, increased content of polyphenols results from the reduction in oxidation of phenolic products that occurs with the thermal inactivation of oxidative enzymes such as polyphenol oxidase (Jiménez-Monreal et al., 2009; Braga, et al., 2011; Mennella et al., 2012).

Compared to fresh eggplant, soluble flavonoid content was about 3.5 times greater in baked and boiled eggplant and about 5.5 times greater in steamed eggplant (Table 2). Hydrolysable flavonoid content was about 1.5 times greater with boiling and 
more than two times greater with steaming. Baking did not increase hydrolysable flavonoid content compared to fresh eggplant. Grajek \& Olejnik (2010) studied hot air-dried tomato and observed up to two times the lycopene content compared to fresh fruit. Increases in flavonoid content are a result of cellular wall rupture and the breaking of bonding forces between antioxidant substances and the tissue matrix.

The antioxidant capacity by the methods ORAC and DPPH had similar values in soluble and hydrolysable polyphenol and flavonoid content. Overall, the antioxidant capacity methods detected differences among cooking treatments. Other authors have noted a high correlation between the phenolic compound content and their antioxidant capacity (Wu et al., 2004).

\section{Conclusions}

There is a growing interest in how organic production might affect the nutritional characteristics of vegetables and how these effects might vary with different thermal preparation methods. Organic production has been promoted as a way to produce more nutritional foods. Our study did not find consistent differences in polyphenol and flavonoid content and antioxidant capacity of eggplant fruit produced under organic versus conventional cultivation systems. In fact, total monomeric anthocyanin content was three times greater in conventionally produced eggplant compared to fruit produced in the organic system. Phenolic and anthocyanin content, as well as antioxidant capacity, was greater in steamed eggplant compared to fresh, boiled and baked fruit. These differences were consistent no matter the cultivation system used to produce eggplant fruits. While our study was limited to the use of a single eggplant cultivar ('Dancer') and production location, other eggplant cultivars may be more responsive to organic production systems.

\section{Acknowledgements}

This project was supported by the Food Science and Technology Program, University of Puerto, Mayagüez Campus.

\section{References}

Akanitapichat, P., Phraibung, K., Nuchklang, K., \& Prompitakkul, S. (2010). Antioxidant and hepatoprotective activities of five eggplant varieties. Food and Chemical Toxicology, 48(10), 3017-3021. http:// dx.doi.org/10.1016/j.fct.2010.07.045. PMid:20691749.

Asami, D. K., Hong, Y.-J., Barrett, D. M., \& Mitchell, A. E. (2003). Comparison of the total phenolic and ascorbic acid content of freeze-dried and air-dried marionberry, strawberry, and corn grown using conventional, organic, and sustainable agricultural practices. Journal of Agricultural and Food Chemistry, 51(5), 1237-1241. http:// dx.doi.org/10.1021/jf020635c. PMid:12590461.

Association of Official Analytical Chemists - AOAC. (2006). Official methods of analysis of the Association of Official Analytical Chemists. Washington: AOAC. (Method 37.1.68).

Azizah, A. H. (2009). Effect of boiling and stir frying on total phenolics, carotenoids and radical scavenging activity of pumpkin (Cucurbita moschato). International Food Research Journal, 16(1), 45-51.

Braga, P. C., Wang, Y. Y., Sasso, M. D., Culici, M., Verducci, P., Fibiani, M., \& Scalzo, R. (2011). Inhibitory effects on human neutrophil bursts of raw, grilled and boiled eggplant (Solanum melongena L.). Spatula DD, 1(3), 129-135. http://dx.doi.org/10.5455/spatula.20110616110705.

Cao, G., \& Prior, R. L. (1999). Measurement of oxygen radical absorbance capacity in biological samples. Methods in Enzymology, 299, 50-62. http://dx.doi.org/10.1016/S0076-6879(99)99008-0. PMid:9916196.

Cao, G., Sofic, E., \& Prior, R. L. (1996). Antioxidant capacity of tea and common vegetables. Journal of Agricultural and Food Chemistry, 44(11), 3426-3431. http://dx.doi.org/10.1021/jf9602535.

Cao, J., Chen, W., Zhang, Y., Zhang, Y., \& Zhao, X. (2010). Content of selected flavonoids in 100 edible vegetables and fruits. Food Science and Technology Research, 16(5), 395-402. http://dx.doi.org/10.3136/ fstr.16.395.

Concellón, A., Zaro, M. J., Chaves, A. R., \& Vicente, A. R. (2012). Changes in quality and phenolic antioxidants in dark purple american eggplant (Solanum melongena L. cv. Lucía) as affected by storage at $0{ }^{\circ} \mathrm{C}$ and $10^{\circ} \mathrm{C}$. Postharvest Biology and Technology, 66(0), 35-41. http://dx.doi.org/10.1016/j.postharvbio.2011.12.003.

Cools, K., Vicente, A., \& Terry, L. A. (2011). Methodologies for extraction, isolation, characterization and quantification of bioactive compounds. In L. A. Terry (Ed.), Health-promoting properties of fruit and vegetables (pp. 371-377). Preston: CAB International.

Das, S., Raychaudhuri, U., Falchi, M., Bertelli, A., Braga, P. C., \& Das, D. K. (2011). Cardioprotective properties of raw and cooked eggplant (Solanum melongena L). Food \& Function, 2(7), 395-399. http:// dx.doi.org/10.1039/c1fo10048c. PMid:21894326.

Dewanto, V., Wu, X., \& Liu, R. H. (2002). Processed sweet corn has higher antioxidant activity. Journal of Agricultural and Food Chemistry, 50(17), 4959-4964. http://dx.doi.org/10.1021/jf0255937. PMid:12166989.

Di Rienzo, J. A., Casanoves, F., Balzarini, M. G., Gonzalez, L., Tablada, M., \& Robledo, C. W. (2013). InfoStat versión 2013. Argentina: Universidad Nacional de Córdoba. Retrieved from http://www. infostat.com.ar/

Donado-Pestana, C. M., Salgado, J. M., Rios, A. O., Santos, P. R., \& Jablonski, A. (2012). Stability of carotenoids, total phenolics and in vitro antioxidant capacity in the thermal processing of orangefleshed sweet potato (Ipomoea batatas Lam.) cultivars grown in Brazil. Plant Foods for Human Nutrition, 67(3), 262-270. http:// dx.doi.org/10.1007/s11130-012-0298-9. PMid:22802046.

Faller, A. L. K., \& Fialho, E. (2009). The antioxidant capacity and polyphenol content of organic and conventional retail vegetables after domestic cooking. Food Research International, 42(1), 210-215. http://dx.doi.org/10.1016/j.foodres.2008.10.009.

Fategbe, M., Ibukun, E., Kade, I., \& Rocha, J. (2012). A comparative study on ripe and unripe eggplant (Solanum melongena) as dietary antioxidant sources. Journal of Medicinal Plants Research, 7(6), 209-218.

Grajek, W., \& Olejnik, A. (2010). The influence of food processing and home cooking on the antioxidant stability in foods. J. Smith \& E. Charter (Eds.), Functional food product development (Functional Food Science and Technology, pp. 178-205). Chichester: Wiley-Blackwell.

Huang, D., Ou, B., Hampsch-Woodill, M., Flanagan, J. A., \& Prior, R. L. (2002). High-throughput assay of oxygen radical absorbance capacity (ORAC) using a multichannel liquid handling system coupled with a microplate fluorescence reader in 96-well format. Journal of Agricultural and Food Chemistry, 50(16), 4437-4444. http://dx.doi.org/10.1021/jf0201529. PMid:12137457.

Huang, Z., Wang, B., Eaves, D. H., Shikany, J. M., \& Pace, R. D. (2009). Total phenolics and antioxidant capacity of indigenous vegetables in the southeast United States: Alabama Collaboration for Cardiovascular Equality Project. International Journal of Food Sciences and Nutrition, 
60(2), 100-108. http://dx.doi.org/10.1080/09637480701605715. PMid:17886092.

Isabelle, M., Lee, B. L., Lim, M. T., Koh, W.-P., Huang, D., \& Ong, C. N. (2010). Antioxidant activity and profiles of common vegetables in Singapore. Food Chemistry, 120(4), 993-1003. http://dx.doi. org/10.1016/j.foodchem.2009.11.038.

Jiménez-Monreal, A. M., García-Diz, L., Martínez-Tomé, M., Mariscal, M., \& Murcia, M. A. (2009). Influence of cooking methods on antioxidant activity of vegetables. Journal of Food Science, 74(3), H97-H103. http://dx.doi.org/10.1111/j.1750-3841.2009.01091.x. PMid:19397724.

Koponen, J. M., Happonen, A. M., Mattila, P. H., \& Törrönen, A. R. (2007). Contents of anthocyanins and ellagitannins in selected foods consumed in Finland. Journal of Agricultural and Food Chemistry, 55(4), 1612-1619. http://dx.doi.org/10.1021/jf062897a. PMid:17261015.

Leyva, D. E. (2009). Determinación de antocianinas, fenoles totales y actividad antioxidante (Master thesis). Universidad Tecnológica de la Mixteca, Huajuapan de León, Oaxaca, México.

Lima, G. P. P., Da Rocha, S. A., Takaki, M., Ramos, P. R. R., \& Ono, E. O. (2008). Comparison of polyamine, phenol and flavonoid contents in plants grown under conventional and organic methods. International Journal of Food Science \& Technology, 43(10), 1838-1843. http:// dx.doi.org/10.1111/j.1365-2621.2008.01725.x.

Mennella, G., Lo Scalzo, R., Fibiani, M., D’Alessandro, A., Francese, G., Toppino, L., Acciarri, N., Almeida, A. E., \& Rotino, G. L. (2012). Chemical and bioactive quality traits during fruit ripening in eggplant (S. melongena L.) and allied species. Journal of Agricultural and Food Chemistry, 60(47), 11821-11831. http://dx.doi.org/10.1021/ jf3037424. PMid:23134376.

Raigón, M. D., Prohens, J., Muñoz-Falcón, J. E., \& Nuez, F. (2008). Comparison of eggplant landraces and commercial varieties for fruit content of phenolics, minerals, dry matter and protein. Journal of Food Composition and Analysis, 21(5), 370-376. http://dx.doi. org/10.1016/j.jfca.2008.03.006.

Raigón, M. D., Rodríguez-Burruezo, A., \& Prohens, J. (2010). Effects of organic and conventional cultivation methods on composition of eggplant fruits. Journal of Agricultural and Food Chemistry, 58(11), 6833-6840. http://dx.doi.org/10.1021/jf904438n. PMid:20443597.

Rufino, M. S. M., Alves, R. E., Brito, E. S., Pérez-Jiménez, J., SauraCalixto, F., \& Mancini-Filho, J. (2010). Bioactive compounds and antioxidant capacities of 18 non-traditional tropical fruits from Brazil. Food Chemistry, 121(4), 996-1002. http://dx.doi.org/10.1016/j. foodchem.2010.01.037.

Sadilova, E., Stintzing, F. C., \& Carle, R. (2006). Anthocyanins, colour and antioxidant properties of eggplant (Solanum melongena L.) and violet pepper (Capsicum annuum L.) peel extracts. Zeitschrift fur Naturforschung C, 61(7-8), 527-535. http://dx.doi.org/10.1515/ znc-2006-7-810. PMid:16989312.

Singh, A. P., Luthria, D., Wilson, T., Vorsa, N., Singh, V., Banuelos, G. S., \& Pasakdee, S. (2009). Polyphenols content and antioxidant capacity of eggplant pulp. Food Chemistry, 114(3), 955-961. http:// dx.doi.org/10.1016/j.foodchem.2008.10.048.

Todaro, A., Cimino, F., Rapisarda, P., Catalano, A. E., Barbagallo, R. N., \& Spagna, G. (2009). Recovery of anthocyanins from eggplant peel. Food Chemistry, 114(2), 434-439. http://dx.doi.org/10.1016/j. foodchem.2008.09.102.

Waterhouse, A. L. (2002). Determination of total phenolics. In R. E. Wrolstad (Ed.), Current protocols in food analytical chemistry (I1.1.1-I1.1.8). New York: John Wiley \& Sons. http://dx.doi. org/10.1002/0471142913.faa0101s06.

Willer, H., \& Lernoud, J. (2014). The world of organic agriculture: statistics and emerging trends 2014 (14th ed., Vol. 2). Bonn, Alemania: FiBL/IFOAM.

Wu, X., Beecher, G. R., Holden, J. M., Haytowitz, D. B., Gebhardt, S. E., \& Prior, R. L. (2004). Lipophilic and hydrophilic antioxidant capacities of common foods in the United States. Journal of Agricultural and Food Chemistry, 52(12), 4026-4037. http://dx.doi.org/10.1021/ jf049696w. PMid:15186133.

Zhang, D., \& Hamauzu, Y. (2004). Phenolics, ascorbic acid, carotenoids and antioxidant activity of broccoli and their changes during conventional and microwave cooking. Food Chemistry, 88(4), 503509. http://dx.doi.org/10.1016/j.foodchem.2004.01.065. 